\title{
ISOLATION, PRODUCTION AND CHARACTERIZATION OF ALKALO THERMOSTABLE XYLANASE FROM NEWLY ISOLATED BACILLUS SP
}

\author{
HIREMATH K.S. AND PATIL C.S.* \\ Department of Biotechnology B.V.Bhomraddy College, Bidar \\ *Corresponding author. E-mail: drcspatil1251@yahoo.co.in, drcspatil1960@gmail.com
}

Received: April 01, 2010; Accepted: April 20, 2011

\begin{abstract}
This research focused on isolation, purification and characterization of new strain of bacillus, which was able to producing extracellular alkaline thermostable xylanase. Xylanase production by alkalo thermostable Bacillus species were isolated from different regions of Bidar, India and used to screen for the xylanase production by using Xylan plate assay. The paper and sugar industrial waste are used to screen and produce the xylanase, the industrial wastes of paper industry showed the maximum synthesis of xylanase at pH ranging from 9 to 12 and temperature 35 to $70^{\circ} \mathrm{C}$ after $18-24 \mathrm{~h}$. The produced Alkalo thermostable xylanase by Bacillus species showed the most xylanolytic activity at $\mathrm{pH}>10$ and temperature of $70^{\circ} \mathrm{C}$.
\end{abstract}

Key words: Xylan, Oat spelt xylan, Xylanase, Xylan assay.

\section{INTRODUCTION}

Microbial xylanases have important applications in the degradation of xylan. Substrate xylan, a biopolymer comprising of D-xylose monomers linked through $\beta-1$, 4-glycosyl bond, is found abundantly in lignocellulosic biomass. Xylanase is produced by many bacteria and fungi (Marta et al., 2000; et al., 2005) and possesses a range of industrial and environmental applications. It can be classified as endo- and exo-xylanases (Min-Jen et al., 2002). Exo-xylanase (ß-D-xylopyranosidase) is sometimes referred to as extracellular xylanase. Bacillus species secrete appreciable levels of extracellular xylanases (Srinivasan and Meenakshi, 1999). Industries that have demand for xylanase are paper and pulp, baking for improving dough handling and quality of baked products, Process of removing lignin from wood in pulp and paper industry is facing serious problem due to the use of chlorine as a bleaching agent since this compound is very toxic to the environment. Indonesia, one of the largest pulp and paper producing countries, is also facing this problem. An alternative method using xylanase for delignifying lignin is a promising method since, in addition to its environmentally friendly technology; this method is easy to apply which does not require major modification of the existing pulping / bleaching processes. Production of xylanase has been performed by many researchers as reported in many reviews [1-3]. Xylanases have mainly been produced from fungal and bacterial strains of microorganism. Although bacterial xylanase were reported to have higher value of optimum $\mathrm{pH}$ which is beneficial from the view point of applying in biobleaching process, xylanase produced from Bacteria usually has higher activity [1]. Higher activity of crude enzyme is very important especially when the enzyme is to be applied in its crude form not in pure condition. Type of strains is close related to type of media used for cultivation. Bacterial strains usually prefer solid state fermentation media which has low water content. On the contrary, bacterial strains prefer submerged fermentation which has high water content. These media types are one of the most responsible factors for the higher value of crude enzyme activity obtained from fungal strains. Although many reports are available concerning the purification of xylanase, application of xylanase to biobleaching process as well as molecular studies of xylanase, there is no report concerning a stepwise optimization strategy to obtain higher enzymatic activity and productivity from fungal strain of microorganisms in its crude form as well as a stepwise strategy of enzyme purification. All factors responsible for increasing enzyme activity and productivity, especially in its crude form, need be investigated since these are of vital importance from industrial point of view. The research aims to study the increasing of activity and productivity of xylanase from xylanase-producing strains of microorganism Bacillus as well as study the purification strategy of crude enzyme. 
The enzyme finds applications in textile industry for degumming of plant fiber sources as well as to enhance fiber quality (Bindu et al., 2007; Aysegul et al., 2008; Vasimon et al., 2007). Xylanase gene has also been cloned to study the recombinant protein in different hosts like Escherichia coli (Ping et al., 2006). The present study has an objective of partially purifying and characterizing the enzyme obtained from soil bacterial isolate producing xylanase. We also intended to look for a favorable property in terms of activity over a broad range of $\mathrm{pH}$. Xylanase activity in alkaline $\mathrm{pH}$ is particularly desirable in operation of biobleaching of pulp. Since chlorine has associated toxicity upon exposure to both humans and environment, partial or full replacement of chlorine as commercial bleaching agent by xylanase, an industrially important enzyme, may be a possibility.

\section{Materials and Methods}

Isolation and screening of Bacteria for xylanase Samples of alkaline soil, paper industry wastes were collected from different areas of Bidar. A total 30 isolates were obtained from soil sample(@5$10 \mathrm{w} / \mathrm{v})$ were incubated into nutrient agar $(\mathrm{pH} 8-12)$ were incubated at $45^{\circ} \mathrm{C}$ with constant shaking at $200 \mathrm{rpm}$ for $72 \mathrm{~h}$. Periodically, the samples from enriched broth were withdrawn, appropriately diluted and plated on basal salt agar medium containing oat spelt xylan $(0.5 \% \mathrm{w} / \mathrm{v})$. The plates were incubated at $45^{\circ} \mathrm{C}$ for $48 \mathrm{~h}$ and colonies developed were assayed for xylanase production by congored $(0.1 \%)$ for $15 \mathrm{~min}$ and then washed with $1 \mathrm{M} \mathrm{Nacl}$. The colonies showing halos around them were picked and maintained on nutrient agar slants at $4^{\circ} \mathrm{C}$.

\section{Enzyme production}

The newly isolated Bacillus sp.was grown in $5 \mathrm{ml}$ Nutrient Broth (NB) medium under shaking at 150 rpm for $18-20 \mathrm{~h}$ at $37^{\circ} \mathrm{C}$. One percent (v/v) of inoculum was transferred into $100 \mathrm{ml}$ of NB , which contained $1.0 \%$ (w/v) xylan, or corncob powder After $18 \mathrm{~h}$ of incubation, the culture was centrifuged at $4^{\circ} \mathrm{C}, 10,000 \mathrm{~g}$ for $10 \mathrm{~min}$ and the cell-free supernatant was stored at $-20^{\circ} \mathrm{C}$ for further studies.

\section{Determination of enzyme activities}

Xylanase activity was determined by the modified method of Okeke and Obi (1995) by performing the reaction mixture of $0.1 \mathrm{ml}$ of cell free supernatant and $0.1 \mathrm{ml}$ of $1 \%(\mathrm{w} / \mathrm{v}$ ) xylan (Sigma) in $50 \mathrm{mM}$ citrate phosphate buffer $\mathrm{pH} 5.5$ at $50 \mathrm{oC}$ for $20 \mathrm{~min}$. The amount of reducing sugar released was determined by Dinitrosalicylic acid (DNS) method (Miller, 1959). One unit of enzyme was defined as the amount of enzyme that released xylose $1 \mu \mathrm{mol}$ per min

\section{The effect of $\mathrm{pH}$ on xylanase activity}

The optimum $\mathrm{pH}$ was determined from the reactions of the enzyme and xylan in various $\mathrm{pH}$ of the buffers (citrate phosphate buffer $\mathrm{pH} 3-6$, phosphate buffer $\mathrm{pH} 7-14$ ) at $50 \mathrm{oC}$ for $20 \mathrm{~min}$.

\section{The effect of temperature on xylanase activity}

The optimum temperature was determined from the enzyme activities at various temperatures of 40 $80^{\circ} \mathrm{C}$ for 20 min under the optimum $\mathrm{pH}$ and buffer. The effect of temperature on enzyme stability was measured the remaining activity after incubating the enzyme in optimum $\mathrm{pH}$ buffer at various temperatures $\left(50-80^{\circ}\right)$ for 30 min. Reaction of the enzyme was performed min under the optimum $\mathrm{pH}$ and temperature for $20 \mathrm{~min}$.

\section{Thin layer chromatography (TLC) analysis}

The action pattern of xylanase on xylan hydrolysis was determined by the modified method of Apiraksakorn et al. (2008) for the thin layer chromatography (TLC) with xylose, glucose and cellobiose (Sigma) as standards. Two $\mu$ of the hydrolysation products containing $2 \mu \mathrm{g} / \mu \mathrm{l}$ reducing sugar were applied on TLC plate (Kieselgel 60, Merck) and developed in mixture solvent of butanol: isopropanol: ethanol: deionized water in the ratio of $2: 3: 3: 2$, respectively. The TLC plate was dipped in $0.2 \%(\mathrm{w} / \mathrm{v})$ orcinol in $10 \%(\mathrm{v} / \mathrm{v})$ sulfuric acid in ethanol and further placing in $100 \mathrm{oC}$ for $15 \mathrm{~min}$.

\section{Results and Discussion} Xylanase production by Bacterial isolates Isolates of Bacillus sp were isolated from the paper industrial wastes shows the effective xylanolytic activity at $\mathrm{pH} 12$ and Temperature of $70^{\circ} \mathrm{C}$ and these were selected and checked the further parameters

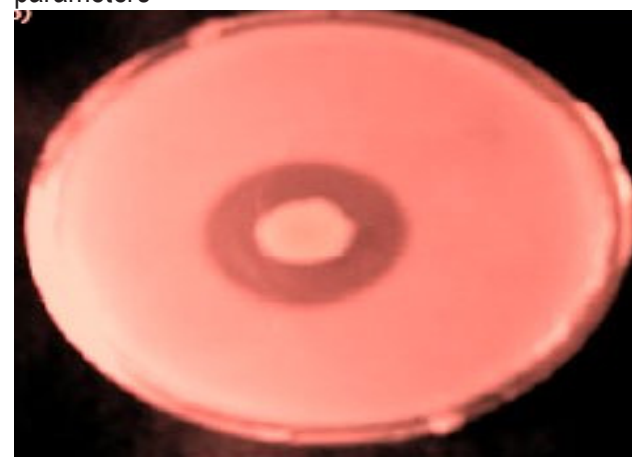

Fig. 1- Bacterial isolate showing zone of hydrolysis which is assayed by congored

The effect of carbon sources on xylanase production

Newly isolated Bacillus sp. is a cellulosic enzyme producing bacteria. It can produce many enzymes revealed with cellulosic material hydrolysis such as 
$\beta-1,3-1,4-$ glucanase, carboxymethylcellulase and xylanase (Apiraksakorn et al., 2006). However, xylanase activity of $0.56 \mathrm{U} / \mathrm{ml}$ was produced by using $1 \%(\mathrm{w} / \mathrm{v})$ carboxymethylcellulose (CMC) as a carbon source (Apiraksakorn et al., 2006). To improve the production of xylanase from Bacillus $s p$, xylan and corncob powder were tested separately as carbon sources. Considering corncob component, it composes of xylan $35-40 \%$ which is the highest amount of xylan found from agricultural residues (Tan et al., 2008, Yang et al., 2005, Yang et al., 2006). Therefore, corncob powder was chosen as a natural xylan source for comparing with commercial xylan (Sigma). By varying the carbon source concentrations from $0-2 \%(w / v)$, the xylanase production from xylan containing medium was higher than those from corncob powder containing medium in all treatments (Figure 2). Moreover, xylanase was significantly higher produced in all treatments than those from the control with no carbon source added. This would be described by the concept of gene expression that xylanolytic enzymes is regulated by the carbon source in the medium and the induction of xylanase take place in the presence of an inducer molecule (Parachin et al., 2009). The result from this study confirmed that xylanase is an inducible enzyme; its activity could be enhanced along with an increase of the appropriate inducer concentrations. The highest xylanase activity of $1.47 \mathrm{U} / \mathrm{ml}$ was obtained from the production medium supplement with xylan $1.5 \%(w / v)$, which was 2.6 fold higher than those of previously reported by using $1 \%$ (w/v) CMC as the inducer (Apiraksakorn et al., 2006). Consider to same concentration of the inducer at $1 \%(\mathrm{w} / \mathrm{v})$, the xylanase production from xylan, corncob powder and CMC were 1.10, 0.76 and $0.56 \mathrm{U} / \mathrm{ml}$, respectively. Therefore, xylan was the most suitable carbon source for xylanase induction.

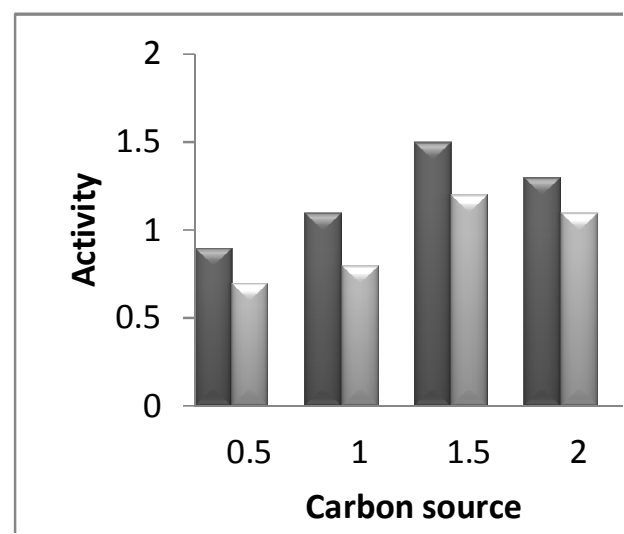

Xylan

Corncob powder
The effect of $\mathrm{pH}$ on xylanase activity

The optimum $\mathrm{pH}$ of xylanase was determined at $50^{\circ} \mathrm{C}$ of various $\mathrm{pH}$ values from $3-14$. The highest activity was shown at $\mathrm{pH} 12$, while xylanase activity was effective at wide range of $\mathrm{pH} 9-12$ with relative activity more than $75 \%$ (Figure 3). Generally, xylanases from Bacillus sp. show optimum $\mathrm{pH}$ around alkaline at $\mathrm{pH} 8-12$, those have been proposed from Bacillus sp. According to the optimum $\mathrm{pH}$ xylanase from Bacillus $s p$. can be grouped into alkaline xylanase. Even alkaline xylanases are more familiar due to their application in the pulp and paper industry, but a few xylanases in acid group could be a key enzyme to improve the bioconversion of lignocellulosic materials (Parachin et al., 2009).

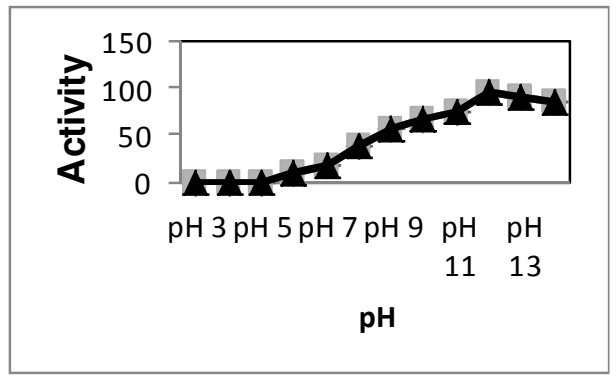

The effect of temperature on xylanase activity The optimum temperature for xylanase was observed at various temperatures from $20-70^{\circ} \mathrm{C}$. The highest xylanase activity was at $70^{\circ} \mathrm{C}$, while it could be effective in the range of from $50-80^{\circ} \mathrm{C}$ with the relative activity more than $70 \%$ as shown in Figure 4. Considering stability of xylanase on temperatures, it was stable at $50-80^{\circ} \mathrm{C}$ for $30 \mathrm{~min}$ with remaining activity around $55 \%$ (Figure 4). Xylanases from Bacillus sp. usually effective at the temperature around $50-80^{\circ} \mathrm{C}$ (Dey et al., 1992; Park et al., 1992; Blanco et al., 1995), except those from other Bacillus sp. (Bataillon et al., 2000) which showed optimum and temperature stability at $75^{\circ} \mathrm{C}$ and $70^{\circ} \mathrm{C}$, respectively and it could be classified as thermostable xylanase.

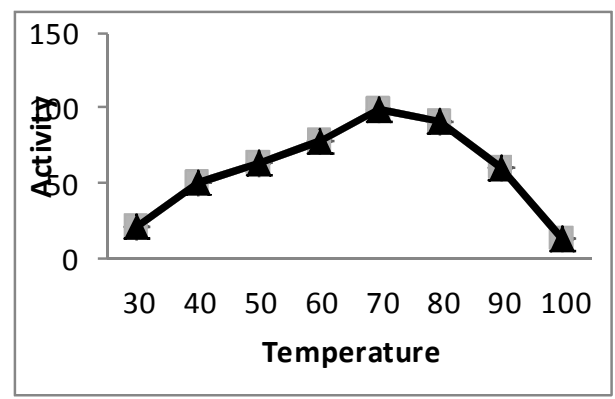

\section{The hydrolysation product}

The degradation products from the action of xylanase on xylan were analyzed by thin layer chromatography and the result was shown as 
Figure 5. Considering the product mobilities compared to those of the standard; xylose, glucose and cellobiose, the results shows that the xylan degradation products from xylanase activity were xylose and 3 different kinds of xylooligosaccharides. From the action pattern, it indicates that xylanase from Bacillus sp. was endoxylanase. Xylo-oligosaccharides are the mixture of oligosaccharides derived from break down the $\beta$ 1,4-linkages of xylan-containing substrate with endoxylanase. Normally, the major products are xylobiose and xylotriose (Yang et al., 2006). The hydrolysis patterns of xylanases from Bacillus $\mathrm{sp}$. NCIM 59 demonstrated that xylanases were endoxylanase. They yielded mainly xylobiose, xylotriose, and higher xylooligosaccharides, with traces of xylose from xylan.

(Dey et al., 1992). Purified xylanase from Bacillus sp. showed the products of bichwood xylan hydrolysis were xylose, xylobiose, xylotriose and xylotetraose, while the major products of wheat bran arabinoxylan and oat spelt xylan hydrolysate were xylode, xylobiose and arabinoxylan (Bataillon et al., 2000). From several previous reports, it is concluded that bacterial xylanases release various products depend on strain of organisms and substrates used.

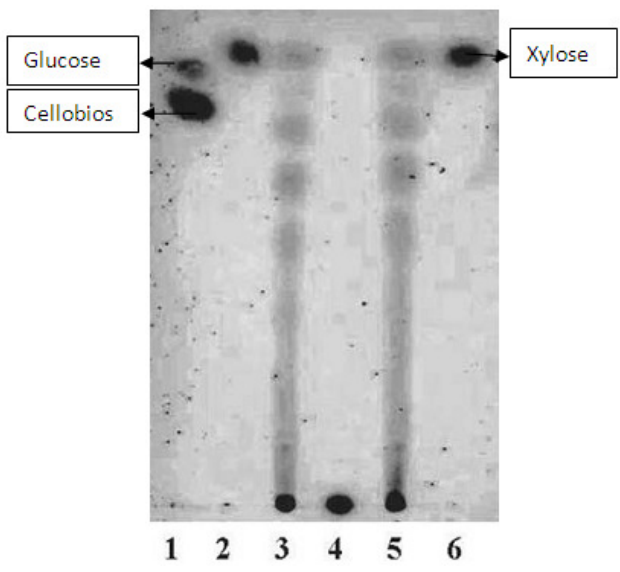

\section{Conclusion}

Xylanase from Bacillus sp. was an inducible enzyme, its activity could be enhanced along with an increase of xylan and corncob powder. The highest xylanase activity of $1.47 \mathrm{U} / \mathrm{ml}$ was obtained from the production medium supplement with xylan $1.5 \%$ (w/v). Xylanase showed optimum $\mathrm{pH}$ and optimum temperature at 9 and $60 \mathrm{oC}$, respectively. It was stable at $50-80^{\circ} \mathrm{C}$ for 30 min with remaining activity around $55 \%$. The hydrolysation products from the action of xylanase were xylose and 3 different kinds of xylooligosaccharides. From the action pattern, it indicated that xylanase from $B$. subtilis GN156 was an endoxylanase.

\section{References}

[1] Apiraksakorn J., Nitisinprasert S. and Levin R.E. (2008) Appl Biochem Biotechnol., 149: 53-66.

[2] Bataillon M., Nunes Cardinali A.P., Castillon N. and Duchiron F. (2000) Enz Microbiol Tech., 26: 187-192.

[3] Blanco A., Teresa V., Colom J.F. and Pastor J. (1995) Appl Environ Microbiol., 61: 4468- 4470.

[4] Breccia J.D., Matiasson B. and Siñeriz F. (1998) J Biotechnol., 61: 219-223.

[5] Dhillon A., Gupta J.K. and Khanna S. (2000) Process Biochemistry, 35: 849856

[6] Miller G.L. (1959) Anal Chem., 31: 426428.

[7] Morales P., Madarro A., González J.A.P. Sendra J.M., Piñaga $F$. and Flors A. (1993) Appl Environ Microbiol. 59: 13761382.

[8] Nabarlatz D., Ebringerová A. and Montané D. (2007) Carbohydrate Polymer, 69: 20-28. 350.

[9] Okeke B.C. and Obi S.K.C. (1995) Biores Technol. 51: 23-27.

[10] Parachin N.S., Siqueira S., de Faria F.P., Torres F.A.G. and de Moraes L.M.P. (2009) J Molecular Catalysis B: Enzymatic, 59: 52-57.

[11] Park Y.S., Yum D.Y., Bai D.H. and Yu J.H. (1992) Biosci Biotech Biochem. 56: 1355-356.

[12] Sá-Pereira P., Mesquita A., Duarte J.C., Barros M.R.A. and Ferreira M.C. (2002) Enzyme Microb Technol., 30: 924-933.

[13] Tan S.S., Li D.Y., Jiang Z.Q., Zhu Y.P., Shi B. and Li L.T. (2008) Bioresource Technol., 99: 200-204.

[14] Vázquez M.J., Alonso J.L., Domínguez H. and Parojó J.C. (2006) Industrial Crops and Products, 24: 152- 159.

[15] Wang Y. and Zhang J. (2006) J Food Engineering, 77: 140-145.

[16] Yang R., Zhang C., Feng $H$. and Yang W. (2006) Biosystem Engineering, 93(4): 375-382. 